failure, and thrombosis of the right main pulmonary artery was suspected during life. At post-mortem, there was massive thrombosis-in-situ of her main pulmonary arteries.
My thanks are due to Sir Russell Brock and Dr. p을 Harvey for permission to publish this case report; alscå to Dr. R. Daley for his helpful advice and criticismsz

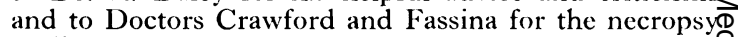
findings.

\title{
REFERENCES
}

Ball, K. P., Goodwin, J. F., and Harrison, C. V. (1956): Massive Thrombotic Occlusion of Large Pulmonaryo Arteries, Circulation, 14, 766.

Brenner, O. ( 1931 ): Sclerosis of the Pulmonary Artery with Thrombosis, Lancet, ii, 91 I.

Cheney, G., and Clarke (1927): Ayerza's Disease: with a report of two cases, Amer. F. med. Sci., 174, 34.

Daley, R., in Daley, R., Goodwin, J. F., and Steiner, R. E., Ed. (1960): Clinical Disorders of the Pulmonary Circulation, p. 270. London: J. \& A. Churchill.

DammanN, J. F., Jr., and Ferencz, C. (1956): Significance of Pulmonary Vascular Bed in Congenital Heart Disease Defects between Ventricles or Great Vessels in which Both Increased Pressure and Blood Flow may act upon $\vec{\circ}$ Lungs and in which there is Common Ejectile Force, Amer. Heart F., 52, 210.

Dawes, G. S., in Adams, W. R., and Veith, I., Ed. (1959): Pulmonary Circulation, p. 270. New York: Grune $\alpha_{\vec{\omega}}$ Stratton.

Dimond, E. G., and Jones, T. R. (1954): Pulmonary Artery Thrombosis Simulating Pulmonic Valve Stenosis with? Patent Foramen Ovale, Amer. Heart Y., 47, 105. Evwards, J. E. (1957): Functional Pathology of the Pulmonary Vascular Tree in Congenital Cardiac Disease, $\frac{3}{6}$.
Circulation, 15, 164.

Goodwin, J. F., in Daley, R., Goodwin, J. F., and Steiner, R. E., Ed. (ig60): Clinical Disorders of the Pulmonary Circulation, p. 270. London: J. \& A. Churchill.

Magidson, O., and Jacobson, G. ( 1 955): Thrombosis of Main Pulmonary Arteries, Brit. Heart f., I7, 207.

Poll, D. (1935): Thrombosis of Pulmonary Vessels in Polycythæmia Vera, F. Mount Sinai Hos., r, 254.

Posselt, A. (1909): Die Erkrankungen der Lungenschlagader, Ergebn. allg. Path. Path. Anat., 13, 298.

Ring, A., and BAKke, J. R. (1955): Chronic Massive Pulmonary Artery Thrombosis, Ann. Intern. Med., 43, 78 I.

Savacool, J. W., and Charr, R. (194I): Thrombosis of Pulmonary Artery, Amer. Rev. Tuberc., 44, 42.

Wood, P. (1956): Diseases of the Heart and Circulation, p. 832. London: Eyre and Spottiswoode.

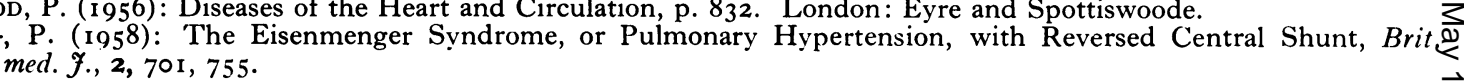

\section{CARCINOID SYNDROME WITH UNUSUAL FEATURES}

\author{
M. A. Hossain, M.B., B.S., F.R.C.S. (Edin.), F.R.C.S. (EnG.) \\ Formerly Surgical Registrar, The Royal London Homoopathic Hospital, Great Ormond Street, London, W.C.I
}

Carcinoli tumours arise from specialized epithelial cells (Kuschitsky cells) of the gastrointestinal tract. These cells can secrete 5 -hydroxytryptamine (5-HT) and an excessive quantity of this substance produces a remarkable syndrome in patients suffering from metastasizing carcinoids with atypical cyanosis, flushing, diarrhœa, asthma-like attacks and, in the late stages, valvular diseases of the right side of the heart (Biörck, Axen and Thornsen, 1952 and Thornsen, Biörck, Bjorkman and Waldenstrom, I954).

The bizarre and inconstant nature of the symptoms can lead to diagnostic error as happened in the following case, the diagnosis of which was not established during life.

\section{Case Report}

A 67-year-old taxi-driver, previously in good health, had a 'heart attack' in 1958 and 'chest trouble' in April, 1959. In August, 1959, while driving, he fainted, hit a car ahead and received head injuries for which he was treated in the hospital. On examination his abdonen was found to be tense and rigid. All other clinical and relevant laboratory findings were within norma응 limits.

In 1960, from May to July, he was investigated foi loss of weight, intermittent back and abdominal pain, episodic diarrhoea and poor urinary stream. Examination revealed periodic increase of muscle tone. At no time was the urinary excretion of 5-hydroxy-indole acetic acid in the urine determined.

On October 4, 1960, he was admitted with retention? of urine due to the enlarged prostate. His prostate waso removed and he had no complications from the operation. During the post-operative period some curious symptoms appeared. He had a brief attack of wheezing and respiratory distress similar to asthma. His face which was permanently red with telangiectases on thळ cheek and nose, showed unusual changes of colour, i.e. flushing with vivid redness, patches of cyanosis on a re background and blanching. A peculiar mental change was observed. $\mathrm{He}$ was slow to speak and answer questions, his face dull and expressionless. He showed limited movements and activity. Occasionally he lay in bed motionless, completely withdrawn from his sur roundings. He would stand with body slightly flexed his gait was slow with short steps not unlike that of Parkinsonism. 'There were no tremors. Sensation anct 


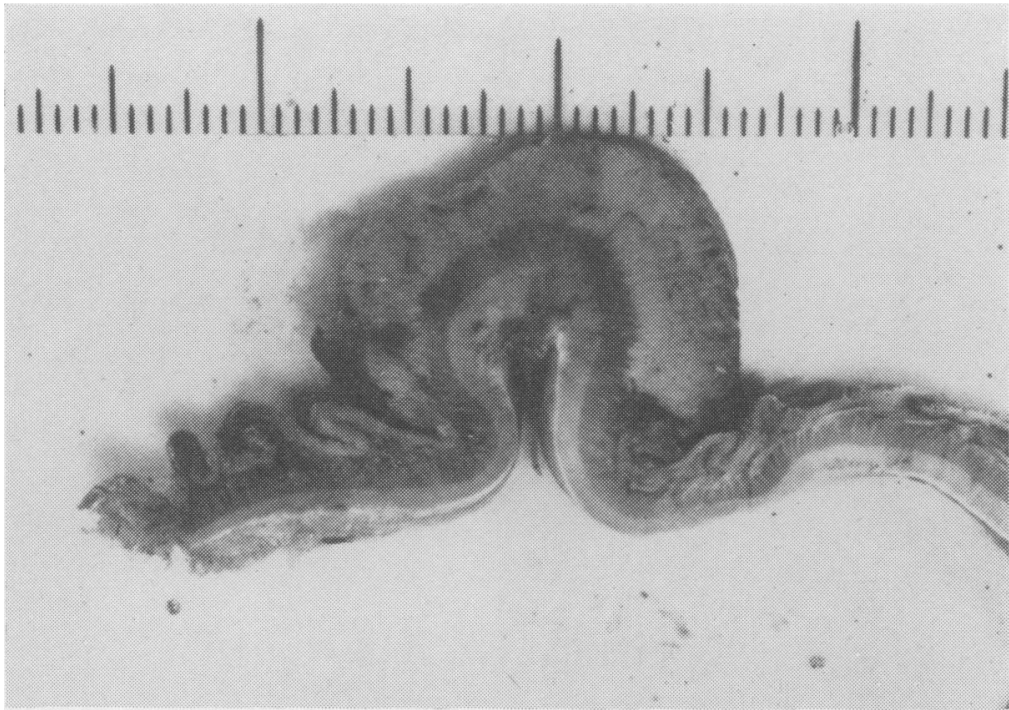

Fig .I.-Showing primary carcinoid tumour in ileum and hypertrophy of the muscle wall.

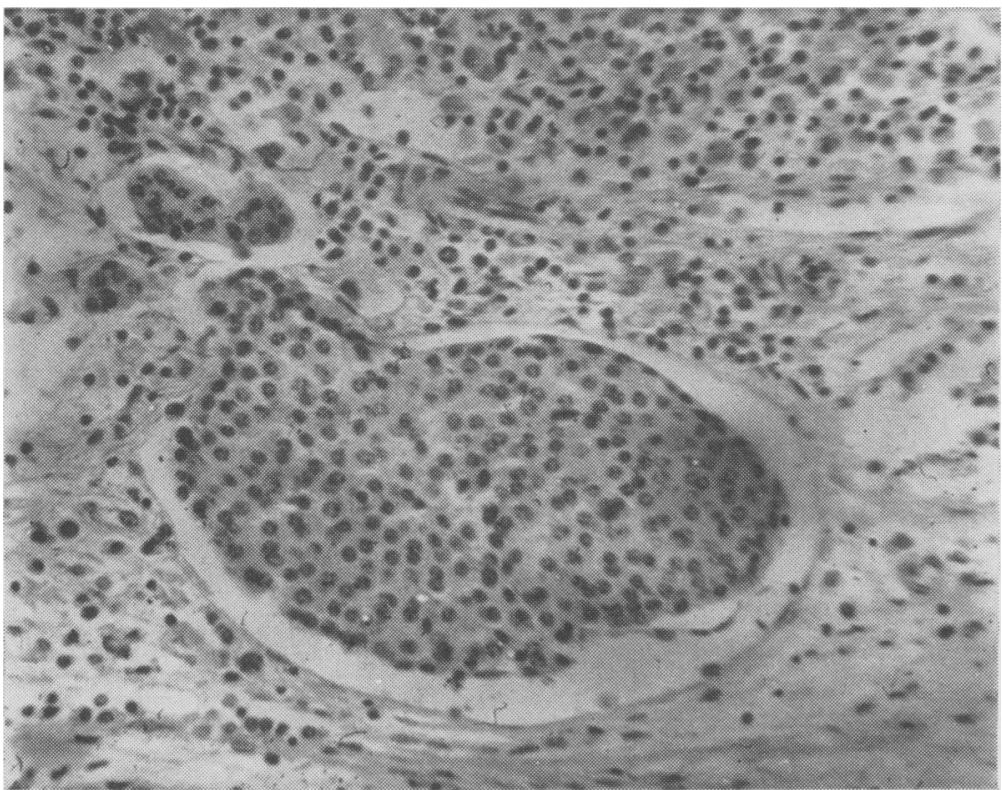

FIG. 2.-Mesenteric glands with metastatic deposits.

reflexes were unaltered. The other striking feature was the periodic increase of muscle tone. At times the abdominal muscles would become so tense and rigid as to make abdominal examination impossible. On November Io, r960, while visiting the toilet he collapsed, became extremely dyspnœic and died quickly.

\section{Autopsy (Dr. Shackle)}

A firm, yellow, invasive carcinoid tumour was found in the ileum (Fig. I). The mesenteric glands (Fig. 2) and the liver contained numerous metastatic deposits. The heart, the brain and their vessels were normal.

Histology. The tumour and the metastases (Fig. 3) showed the typical histology of carcinoid tumour with fine dusting and open appearance of the nuclear chromatin, and argentaffin granules (Fig. 4) on silver staining. Fluorescence was also observed in ultraviolet light.

\section{Discussion}

Malignant carcinoids are slowly growing tumours. Even with widespread metastases long periods of survival have been recorded (Cope, I930; Mallory I940).

The extensive metastases in this patient suggest $\stackrel{Ð}{\rightarrow}$ that he had had this tumour for a long time. Had 7 all his symptoms since $195^{8}$ been correlated and due attention paid to his permanently red face, 


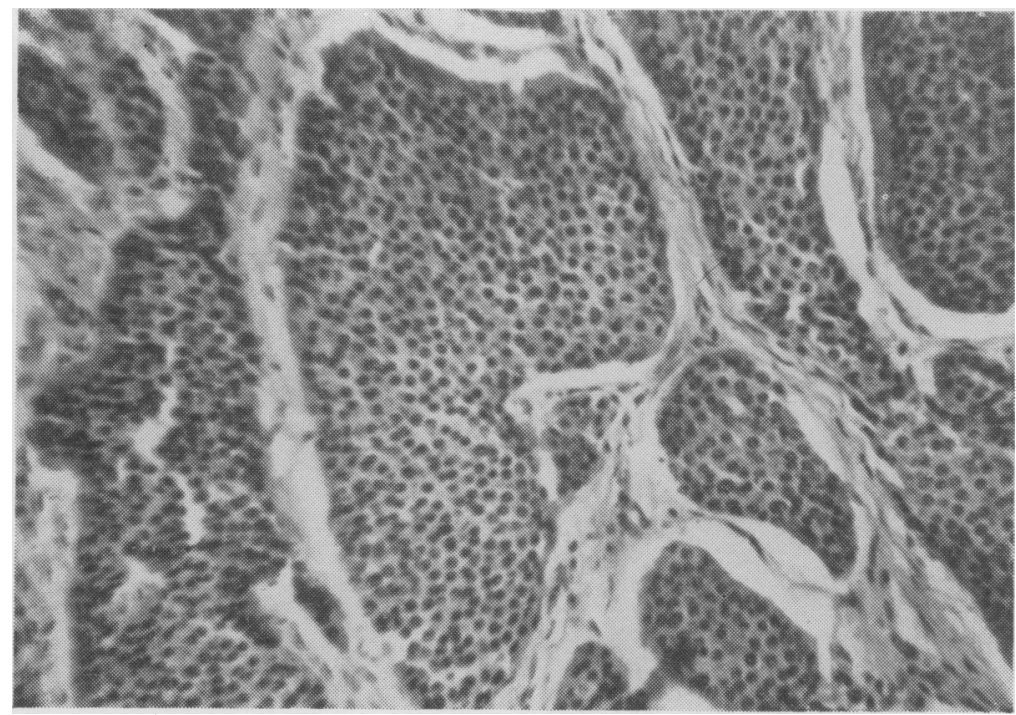

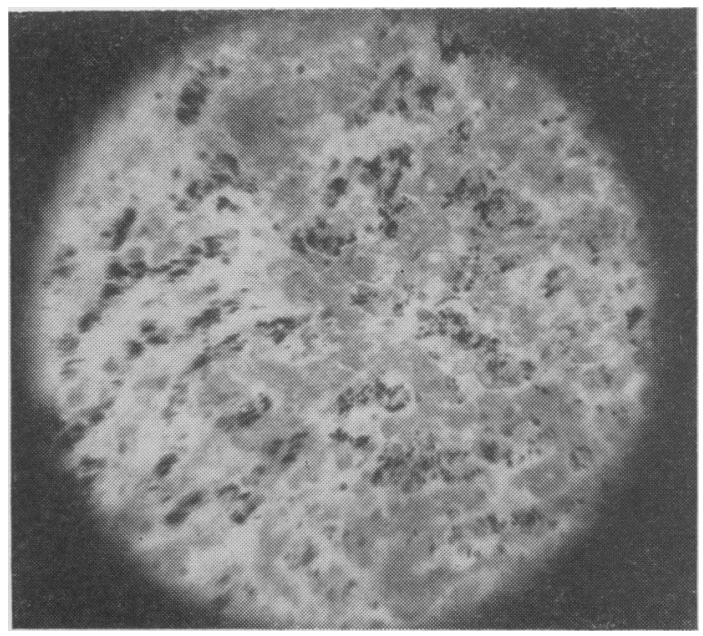

FIG. 4.-Section showing argentaffin granules.

telangiectases and colour changes, a correct diagnosis could have been established.

The co-existence of peculiar mental change and periodic increase of muscle tone with abdominal rigidity are the most interesting and unusual features in this case. I have not been able to find a comparable case in the literature. There were no major arteriosclerotic changes nor was there any deficiency of nicotinic acid, which sometimes arises in this syndrome, to account for the mental change in this patient. As for the abdominal rigidity and increased muscle tone, there was no pain, tenderness or peritoneal irritation or any other peripheral factor to be held responsible for it. It appears that $5-\mathrm{HT}$ was in some way responsible for the production of these symptoms.

Large quantities of $5-\mathrm{HT}$ have been found in the brain and nerve ganglia (Page and Twarog, $\varnothing$ 1953; Amin, Crawford and Gaddum, 1954), ando the enzymes decarboxylase and monoamine-oxidase that form and destroy it have also been discovered $\bar{z}$ (Undenfriend, Weissbach and Bogdanski, r957) Various investigators have shown (Page and Twarog, 1953; Woolley and Shaw, 1954; Marrazzio and Harts, 1955) that 5-HT plays a part in the? functioning of nervous systems and normal mentalo processes. Injection of $5-\mathrm{H}^{\mathrm{T}} \mathrm{T}$ into the ventricle $\mathrm{O}$ fo a cat produces lassitude and unwillingness to change position like the catatonia seen in mentalo disorders (Feldberg and Sherwood, 1954). Similarlyo administration of 5-hydroxytryptophan (5-HTP;@ serotonin-precursor) in animals produces changes $\overrightarrow{\vec{A}}$ in behaviour (Smith, 1960). Marrazzi suggested 3 that accumulation of 5 - $\mathrm{HT}$ could produce abnormalbehaviour by inhibition of synaptic function. Serotonin is believed to be a chemical transmitter of nerve impulse (Brodie and Shore, 1957) and an intravenous injection can produce repetitive nerve impulses (Schneider and Yonkman, 1953). These experimental observations show that an excess of $5-\mathrm{HT}$ in the brain can produce mental change and? also excite nerve tissues to set up repetitive nerve impulses.

Woolley and Shaw (1954) on the other hand have produced evidence by using several anti-metabolites. that cerebral deficiency of 5-HT is probably responsible for the mental change. The lattet view has been strengthened by the observation of Gaddum (1953).

Although our knowledge of the cerebral meta- $\omega$ bolism of serotonin and the enzymes that form and destroy it, the substance that activates and block $\$$ the enzymes to produce excess or deficiency of $5-\mathrm{HT}$, is insufficient, it is generally recognized that many substances such as LSD, harmala alkaloidso (Woolley and Shaw, 1954) and 5-HTP (Smitho 1960) cause mental disturbance by upsetting the 
5-HT contents of the brain. The possibility exists that some other indole products of the tumour or unidentified intermediary metabolites of $5-\mathrm{HT}$, having structural similarity, may behave in the same way and are capable of producing mental change. Whatever mechanism may be involved for the cerebral metabolism of serotonin, in the light of the above experimental evidences, and in the absence of any other known cause, the neurological and mental symptoms presented by this patient, along with attacks of flushing, strongly suggests that a disturbance of cerebral metabolism of serotonin was responsible for the symptoms.

I am most grateful to Mr. Stephen Power, Con- $\subseteq$ sultant Surgeon, for his generous guidance and helpful $\Rightarrow$ criticisms, and Dr. Shackle for the post-mortem examination and histology slides, Mr. Nicholson and Dr. Shackle for the photographs, and Miss Johns for her secretarial help.

\title{
REFERENCES
}

Amix, A. H., Crawford, T. A. B., and Gaddum, J. H. (1954): The Distribution of Substance P and 5-Hydroxytryptamine in the Central Nervous System of Dog, F. Physiol. (Lond.), r26, 596.

Biörck, G., Axen, O., and Thorson, A. (1952): Unusual Cyanosis in a Bor with Congenital Pulmonary Stenosis and Tricuspid Valve Insufficiency, Fatal Outcome, Amer. Heart $\mathcal{F}$., 44, 143.

Brodie, B. B., and Shore, P. A. (1957): A Concept for a Role of Serotonin and Norepinephrine as Chemical Mediator in the Brain, Ann. N.Y. Acad. Sci., 66, $63 \mathrm{I}$.

Cope, Z. (1 930): Metastases of Argentaffin Carcinoma in Testicle, Brit. F. Urol., 2, 268.

Feldberg, W., and Sherwood, S. L. (1954): Injections of Drugs into the Lateral Ventricle of Cat, F. Phy'siol. (Lond.), 123,148 .

Gaddum, J. H. (1953): Antagonism between Lysergic Acid Diethylamide and 5-hydroxytryptamine, F. Physiol. (Lond.), - I2I, I 5.

MalloRY, T. B. (i940): Case Records of the Massachusetts General Hospital, New Engl. F. Med., $222,686$.

Marrazzi, A. S., and Harts, E. R. (1955): Relationship of Hallucinogens to Adrenergic Cerebral Neurohumors, Science, 121, 365 .

Page, I. H., and Twarog, B. M. (1953): Serotonin Content of Some Mammalian Tissues, Urine and Method for its Determination, Amer. F. Physiol., I75, 157.

Schneider, J. A., and Yonkman, F. F. (1953): Action of Serotonin on Vagal Afferent Impulses in Cat, Amer. $\mathcal{F}$. Physiol., 174, 127.

Thorson, A., Biörck, A., Bjorkman, G., and Waldenstrom, J. (r954): Malignant Carcinoid of the Small Intestine with Metastases to the Liver, Valvular Disease of the Right Side of the Heart, Peripheral Vasomotor Symptomso Bronchoconstriction and an Unusual Type of Cyanosis: A Clinical and Pathological Syndrome, Amer. Heart $\mathscr{F}$ 47, 795 .

Undenfriend, S., Weissbach, H., and Bogdanski, D. F. (1957): The Distribution of Serotonin, 5-Hydroxytryptophan̄ Decarboxylase and Monoamine Oxidase in the Brain, $\mathcal{F}$. Neurochem., $\mathbf{1}, 272$.

Woolley, D. W., and Shaw, E. (r954): Some Neurophysiological Aspects of Serotonin, Brit. med. F., ii, r22.

\section{CHRONIC OSTEOMYELITIS OF THE UI،NA OCCURRING IN SYRINGOMYELIA}

\author{
R. S. Phillips, F.R.C.S. \\ The Royal Infirmary, Edinburgh 3
}

Although, in this day and age, acute and chronic osteomyelitis are seen much less than formerly, the conditions are by no means rare. However, chronic osteomyelitis of the ulna in the absence of a compound fracture is uncommon.

Trueta and Morgan (1954) reporting a series of cases of acute osteomyelitis, found the ulna to be the site of infection in four of one hundred patients. Blanche (1952) in his series, found two in 50 patients. Green, Nyhan and Fousek (1956) found the ulna involved in nine, in their series of 99 patients.
However, in these authors' series, the lesion was acute and occurred in infancy or childhood.

Acute and chronic pyogenic osteomyelitis, in adults, are even less common conditions. Reviewing the literature of the past 35 years, a direct reference to the conditions could be found on three occasions only. Variava (1935) described the acute condition in a patient with a compound fracture of both forearm bones. The radius, however, was involved maximally. Dufour (1933) demonstrated the radiological history of one patient with chronic 